\title{
Factors Affecting Safe Sex Behavior Among Female Sex Workers in Surakarta, Central Java
}

\author{
Saras Vati Manvatarini Sugma'), Aris Sudiyanto²), Argyo Demartoto3) \\ 1)Masters Program in Public Health, Universitas Sebelas Maret \\ 2)Department of Psychiatry, Faculty of Medicine, Universitas Sebelas Maret \\ 3)Department of Sociology, Faculty of Social and Political Sciences,Universitas Sebelas Maret
}

\begin{abstract}
Background: Earlier studies often focus solely on clients as female sex worker (FSW) risky sexual partners, ignoring the possible risks FSWs face from steady sex partners. Thus, further study is needed identifying strategies to reduce the potential increased risk of HIV/STI transmission between FSWs and their steady partners. This study aimed to determine factors affecting safe sex behavior among female sex workers in Surakarta, Central Java.

Subjects and Method: A cross-sectional study was conducted in Banjarsari, Surakarta, Central Java, from April to May 2018. A sample of 134 female sex workers was selected by simple random sampling. The dependent variable was safe sex behavior. The independent variables were subjective norm, perceived behavior control, intention, attitude, education, and age. The data were collected by questionnaire and analyzed by path analysis.

Results: Safe sex behavior increased with strong intention $(b=0.08 ; S E=0.04 ; p=0.041)$. Safe sex behavior indirectly increased with older age, positive attitude, positive subjective norm, and strong perceived behavior control.

Conclusion: Safe sex behavior directly increases with strong intention, and indirectly increases with older age, positive attitude, positive subjective norm, and strong perceived behavior control.
\end{abstract}

Keywords: safe sex behavior, Theory of Planned Behavior

\section{Correspondence:}

Saras Vati Manvatarini Sugma. Masters Program in Public Health, Universitas Sebelas Maret, Jl. Ir. Sutami No. 36 A, Surakarta, Central Java. Email: sarasvatims@gmail.com.

Mobile: +6282186653675.

\section{BACKGROUND}

$\overline{\text { Sexually transmitted infections (STIs) have }}$ a profound impact on sexual and reproductive health throughout the world. The cumulative number of STIs from herpes, gonorrhea, syphilis, trichomoniasis, chlamydia, genital warts and ulkusmole cases increased from 63,453 in 2014 to 74,707 in 2015 and increased again in 2016 to 88,042 per 100,000 populations worldwide. STIs can have serious consequences beyond the direct impact on the infection itself and can also increase the risk of transmission of Human Immunodeficiency Virus (HIV) three times or more (WHO, 2013; Braxton, 2017).
The attitude and behavior of modern society today tends to embrace a lifestyle of free sex which consequently has increased the incidence of STIs and HIV/AIDS infections. Commercial Sex Workers (CSWs) are one of the high risk groups affected by STIs and HIV / AIDS as a risk to their profession. CSWs are at high risk of being infected due to the behavior of frequently changing sexual partners, especially when having unsafe sex without using condoms (Ministry of Health, 2010).

The National AIDS Commission also stated that people with STIs and HIV / AIDS in Indonesia were mostly found among Commercial Sex Workers (CSWs) 
with known media transmission through blood, sperm and vaginal / cervical fluid. Sexual relations between commercial sex workers and their customers without using condoms are high-risk behaviors for HIV / AIDS transmission (Irianto, 2015; Budiono, 2012).

Commercial sex workers in Indonesia in 2016 reached 56,000 people with the highest cases of STIs and HIV / AIDS also found in the risk group of Commercial Sex Workers amounting to 9,399 (29.3\%). Central Java ranked 4 th with the number of infections of 1,467 for HIV, 3rd place for AIDS with 1296 infections, 14,302 cases of STIs and with the number of commercial sex workers for about 3,062 people (Isnaeni, 2017; Ministry of Health RI, 2017).

Based on the background, the author interested to analyze the influence of attitudes, subjective norms, perceptions of behavioral control and intention to safe sexual behavior of commercial sex workers in Banjarsari, Surakarta, Central Java.

\section{SUBJECTS AND METHOD \\ 1. Study Design \\ This was an analytic observational study with a cross-sectional design. The study was conducted in Banjarsari, Surakarta, Central Java, from April to May 2018.}

\section{Population and Samples}

The study population was female sex workers in Banjarsari, Surakarta, Central Java. A total of 134 female sex workers was selected by simple random sampling.

\section{Study Variables}

The dependent variable was safe sex behavior. The independent variables were subjective norms, perceptions of behavioral control, intentions, attitudes, and age.

\section{Operational Definition of Variables}

Safe sex behavior was defined as a way of having sex to avoid contracting sexually transmitted diseases, by using condoms during sexual intercourse, using waterbased lubricants, having unprotected sex, and having sex with a loyal partner.

Intention was defined as the desire of the subjects to behave safely by using condoms during sexual intercourse, using water-based lubricant, having sex without penetration and having sex with a loyal partner.

The perception of behavioral control was defined as the belief of the subjects in their ability to control inhibiting factors to choose safe sex behavior.

Subjective norm was defined as the beliefs of the subjects regarding a person's judgment (peers, pimps, customers, health personnel) that influence the decision of the subjects to conduct safe sex behavior.

Attitude was defined as the assessment of subjects whether positive or negative responses on the safe sex behavior.

Age was defined as how old the subject is at the time of research data collection.

\section{Data Analysis}

Univariate analysis was conducted to see mean of SD, minimum, and maximum values. Bivariate analysis was done to analyze the relationship of subjective norms, perception of behavioral control, intention, attitude, and age towards the safe sex behavior. Bivariate analysis was performed by using Pearson product moment test. Multivariate analysis was done using path analysis with AMOS 22.

\section{Research Ethics}

The research ethics includes informed consent, anonymity, confidentiality and ethical clearance. The ethical clearance in this study was conducted at Dr. Moewardi hospital, Surakarta. No: 499 / IV / HREC / 2018. 


\section{RESULTS}

1. Characteristics of Study Subjects The subjects of this study were 134 commercial sex workers in Banjarsari District, Surakarta City. Table 1 shows that each variable has a relatively small amount of data. The mean describes the average value, while the standard deviation (SD) value describes how far the data varies.
Small SD is the indication of representative data.

\section{Bivariate Analysis}

Bivariate analysis was used to see the relationship between independent variables (subjective norms, perception of behavioral control, intention, attitude and age) and the dependent variable (safe sex behavior) based on the results in table 2.

Table 1. Univariate Analysis of Study Variable

\begin{tabular}{lccccc}
\hline \multicolumn{1}{c}{ Variables } & n & Mean & SD & Min. & Max. \\
\hline Safe sex behavior & 134 & 6.26 & 2.77 & O & 10 \\
Subjective Norms & 134 & 38.77 & 7.82 & 17 & 48 \\
The perception of behavior & 134 & 38.42 & 7.66 & 17 & 48 \\
control & 134 & 32.35 & 5.88 & & 40 \\
Intention & 134 & 37.62 & 7.58 & 17 & 48 \\
Attitude & 134 & 35.00 & 9.47 & 19 & 65 \\
Age & & & & &
\end{tabular}

Table 2. Bivariate analysis of the relationship of subjective norms, perceived behavioral control, intention, attitude and age and the safe sex behavior

\begin{tabular}{lcc}
\hline \multicolumn{1}{c}{ Independent Variables } & r & p \\
\hline Subjective Norms & 0.85 & $<0.001$ \\
The perception of behavior control & 0.65 & $<0.001$ \\
Intention & 0.17 & 0.044 \\
Attitude & 0.65 & $<0.001$ \\
Age & 0.48 & 0.060 \\
\hline
\end{tabular}

Based on Table 2, it shows that the results of the Pearson product moment correlation test about the relationship between subjective norms $(\mathrm{r}=0.85 ; \mathrm{p}$ $<0.001$ ), perception of behavioral control ( $\mathrm{r}$ $=0.65 ; \mathrm{p}<0.001)$, intention $(\mathrm{r}=0.17 ; \mathrm{p}=$ $0.044)$, attitude $(\mathrm{r}=0.65 ; \mathrm{p}<0.001)$ and age ( $\mathrm{r}=0.48 ; \mathrm{p}=0.060$ ) with safe sex behavior with results showing that it is statistically significant.

\section{Multilevel Analysis}

Multivariate analysis explained the effect of more than one independent variables on one dependent variable. The method used was path analysis by using the STATA 13 program.Table3 showed that safe sex behavior was affected by intention $(b=0.08$; $\mathrm{SE}=0.04 ; \mathrm{p}=0.041)$, intention was affected by attitude $(b=0.11 ; \mathrm{SE}=0.05 ; \mathrm{p}=0.017)$, perceived behavior control $(\mathrm{b}=0.12 ; \mathrm{SE}=$ 0.04; $p=0.006)$, subjective norm $(b=0.50$; $\mathrm{SE}=0.04 ; \mathrm{p}<0.001)$. Attitude was affected by age $(b=0.10 ; 0.05 ; p=0.043)$, subjective norm $(b=0.39 ; \mathrm{SE}=0.08 ; \mathrm{p}<0.001)$ and perceived behavior control $(b=0.35 ; \mathrm{SE}=$ $0.08 ; \mathrm{p}<0.001$ ).

Figure 1 shows the structural model after estimating using IBM SPSS AMOS 22, so that the values can be seen. The indicator that shows the suitability of the path analysis model, which is in table 3 also shows the goodness of fit measure that the results obtained fit the CMIN index of 7.82 with $\mathrm{p}=0.167$; NFI $=0.98 \geq 0.90$; CFI 0.98 $\geq 0.95$; RMSEA $=0.065 \leq 0.08$ which means that the empirical model meets the specified criteria and is stated in accordance with the empirical data. 


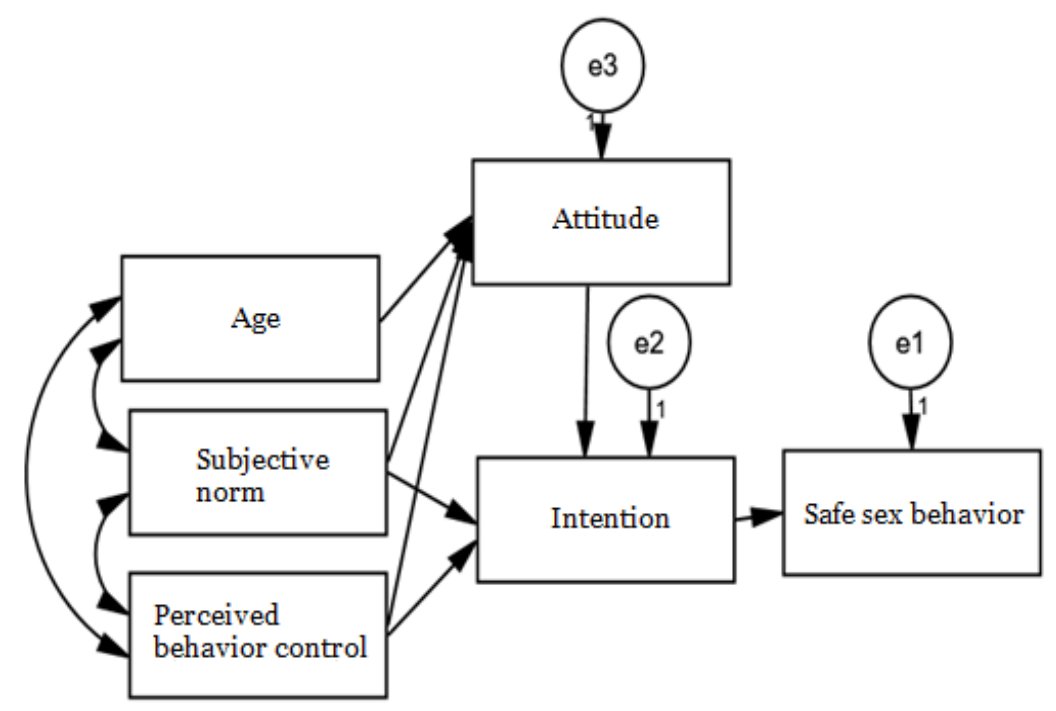

Figure 1. Structural Model of Path Analysis

Table 3.The Results of Path Analysis

\begin{tabular}{|c|c|c|c|c|c|c|}
\hline $\begin{array}{l}\text { Dependent } \\
\text { Variable }\end{array}$ & & Independent Variables & $\mathbf{b}^{*}$ & SE & $\boldsymbol{\beta}^{* *}$ & $\mathbf{p}$ \\
\hline \multicolumn{7}{|l|}{ Fixed Effect } \\
\hline \multicolumn{6}{|l|}{ Random Effect } & 0.041 \\
\hline Intention & & $\begin{array}{l}\text { Perceived Behavior Control } \\
\text { (Strong) }\end{array}$ & 0.12 & 0.04 & 0.16 & 0.006 \\
\hline Intention & & Subjective Norm (positive) & 0.50 & 0.04 & 0.67 & $<0.001$ \\
\hline Intention & \multirow{2}{*}{\multicolumn{2}{|c|}{$\begin{array}{ll}\leftarrow & \text { Attitude (positive) } \\
\leftarrow & \text { Perceived Behavior Control } \\
& \text { (Strong) }\end{array}$}} & 0.11 & 0.05 & 0.14 & 0.017 \\
\hline Attitude & & & 0.35 & 0.08 & 0.35 & $<0.001$ \\
\hline Attitude & & Subjective Norm (positive) & 0.39 & 0.08 & 0.40 & $<0.001$ \\
\hline Attitude & $\leftarrow$ & Age ( $\geq 32$ years old $)$ & 0.10 & 0.05 & 0.13 & 0.043 \\
\hline \multicolumn{7}{|l|}{ FitModel } \\
\hline N Observation $=134$ & \multicolumn{6}{|c|}{$\mathrm{NFI}=0.98$} \\
\hline $\mathrm{CMIN}=7.82$ & \multicolumn{6}{|c|}{$\mathrm{CFI}=0.98$} \\
\hline$p=0.167$ & \multicolumn{6}{|c|}{ RMSEA $=0.065$} \\
\hline \multicolumn{7}{|c|}{${ }^{*} \mathrm{~b}=$ unstandardized path coefficient } \\
\hline$* * \beta=$ standardized pa & coef & cient & & & & \\
\hline
\end{tabular}

\section{DISCUSSIONS}

\section{The relationship between attitude and safe sex behavior among female sex workers}

The result of this study showed that there was a significant relationship between attitude and safe sex behavior through intention. Professions as commercial sex workers with sexually transmitted diseases were a bad circle. Usually, this sexually transmitted disease was mostly suffered by
FSW, where they sell themselves to multiple person without using safety such as condoms (Noviana, 2016).

Attitude was one of the factors that influenced individual behavior. The more positive an individual's attitude to do something, the stronger the individual's intention to do the behavior (Kumalaningrum et al., 2017). 
Attitude was determined by a combination of individual beliefs about the positive and or negative consequences of doing a behavior with an individual's subjective assessment of every consequence in doing a behavior (Mahyarni, 2013).

Lentera (2016) explained that a way to perform sexual activity without being infected by sexually transmitted diseases was by using condoms and not having multiple partners so that a positive attitude was needed to avoid free sex, one of them was safe sex behavior.

Murni et al. (2016)also mentionedthe benefits of safe sex for commercial sex workers were to protect themselves from sexually transmitted diseases such as gonorrhea (GO) or syphilis which would affect health, to protect sex partners from HIV and if the partner was infected by HIV, safe sex could avoid the sex workers to be re-infected with other types of HIV.

Raisyifa (2010) also stated that attitude was one of the factors that affected the formation of a positive behavior. The more positive the attitude of CSW, the better the safe sexual behavior in the prevention of STD and HIV/AIDS.

\section{The relationship between per- ceived behavior control and safe sex behavior among sex workers}

The result of this study showed that there was a significant relationship between perceived behavior control and safe sex behavior through intention.

Widodo (2009) also stated that perceived behavior control described the feeling of self-efficacy or the ability of an individual to conduct a behavior. Strong self-ability would affect someone in behaving.

The stronger the ability to use condoms, the better the condom use behavior. And the stronger the perceived control behavior of commercial sex workers in the prevention of STD and HIV/AIDS, the better the safe sex behavior to prevent STD and HIV/AIDS (Ambarsari, 2018).

Commercial sex workers have an important role in increasing the incidence of STD and their dissemination, this was because the workers were a group of high risk behaviors, therefore, promoting prevention of STD among sex workers was very important to control the spread of STD and strong intentions were needed so that perceived behavior control for safe sexual behavior could prevent the occurrence of sexually transmitted diseases (Demartoto et al, 2017).

\section{The relationship between subjec- tive norm and safe sex behavior among female sex workers}

The result of this study showed that there was a significant relationship between subjective norm and safe sex behavior through intention.

The scientific approach that can be implemented to help in assessing the problem was the Theory of Planned Behavior (TPB), because this approach could identify the motivational influences on behavior outside the individual and also could direct the strategy of changing people's behavior through the measurement of attitude factors, subjective norms and perceived behavior control. These three factors would then influence a person's intention to adopt a behavior, so that the desired behavior can be realized eventually (Albertaet al., 2017).

Subjective norm was a person's perception of social pressure in doing or not doing a considered behavior, related to perceived normative decisions of behavior. The more positive the perception of commercial sex workers in using condoms, the more likely they were to have safe sex behavior in the prevention of STD and HIV/AIDS (Wulandari, 2016). 
Journal of Health Promotion and Behavior (2018), 3(2): 109-115

https://doi.org/10.26911/thejhpb.2018.03.02.04

\section{The relationship between age and safe sex behavior among sex workers}

The result of this study showed that there was a significant relationship between age and safe sex behavior through intention. Intention was a factor in the Theory of Planned Behavior (TPB). The intention was the level of certainty about the practice of behavior. Intention was determined by attitudes and subjective norms. This was in accordance with the results of the study which showed that most research subjects with safe sex behavior have positive subjective norms with an adult age (Alberta et al., 2017).

Age was one of the factors that affect behavior and decision making in certain conditions. At the age of 15-25 years old, there was an integration between the development of psychological age and biological age so that it was highly affected by multifactors that occur in various fields in society, the cases of sexually transmitted diseases were increased, especially HIV/ AIDS, because of too young age, the older the age of a person, the mindset related to health and the security of both self and others was increased, so that safe sex behavior was chosen more often to protect people from diseases.

Yogatama (2013) explained that physiological function of the body would decrease in older age ( $>60$ years old) and as age increased, atherosclerosis and macroangiopathy could occur which can decreased blood circulation so that it can lead to the occurrence of the disease, therefore, the enhancement of age affected health-related mindsets. The older the age of a person, the more mature the strength level of a person in thinking and working, so that the health was more concerned, one of the ways was by conducting safe sex behavior.
Based on the results of the study which used the health model approach of Theory of Planned Behavior, it can be concluded that safe sex behavior was directly influenced by intentions and indirectly influenced by subjective norms, perceived behavior control, intention, attitude, and age.

\begin{tabular}{l}
\hline REFERENCES \\
\hline AlbertaL, Proboningsih J, Almahmudah M \\
(2014). Peningkatan Perilaku Diet \\
Rendah Garam Berbasis Theory of \\
Planned Behavior (TPB) pada Lansia \\
Penderita Hipertensi. Jurnal Ners, \\
9(2): 297-304. \\
Ambarsari M, Demartoto A, Wekadiguna- \\
wan CSP (2018). Factors Associated \\
with Safe Sex Bahavior Among Com- \\
mercial Sex Workers in Banjarsari, \\
Surakarta, Central Java. Journal of \\
Epidemiology and Public Health, \\
3(1):60-71.
\end{tabular}

Braxton J, Davis D, Flagg E, Grey J, Harvey A (2017). Sexually Transmitted Disease Surveillance 2016. Atlanta: U.S Department of Health and Human Services.

Budiono I (2012). Konsistensi Penggunaan Kondom oleh Wanita Pekerja Seks/ Pelanggannya. Jurnal Kesehatan Masyarakat, 7(2): 97-101.

Demartoto A, Zunariyah S, Soemanto RB (2017). Pendidikan Sebaya Terstruktur Responsif AIDS. Surakarta: CV Kekata Group.

Iriaonto (2015). Kesehatan Reproduksi (Reproductive Health) Teori dan Praktikum. Bandung: Alfabeta.

Isnaeni N, Laksono B, Deliana S (2017). Hubungan antara Pengetahuan, Pola Asuh Permisif, Tayangan Pornografi, dan Konformitas Teman Sebaya dengan Perilaku Seks Remaja yang Menggunakan Jasa WPS (Wanita 
Penjaja Seks) di Bandungan Kab. Semarang. Public Health Perspective Journal, 2(1): 34-71.

Kemenkes RI (2010). Pedoman Pencegahan Penularan HIV-AIDS dan IMS bagi Kabupaten/Kota. Jakarta: Direktorat Jendral Pengendalian Penyakit dan Penyehatan Linkungan.

(2017). Laporan Situasi Perkembangan HIV-AIDS \& PIMS di Indonesia Januari-Maret 2017. Jakarta: Ditjen P2P Kementrian Kesehatan RI. World Health Organization. (2013). Sexually Transmitted Infections (STIs). Switzerland: Department of Reproductive Health and Research World Health Organization.

Kumalaningrum M, Pamungkasari E, Nurhaeni I (2017). Multilevel Analysis on the Predictors of Safe Sexual Behavior among Girl Adolescents in Karanganyar, Central Java. Journal of Health Promotion and Behavior, 2(4): 323331.

Lentera GW (2016). Buku Kesehatan dan Hak Seksual serta Reproduksi Remaja. Surabaya: Jaringan Gaya Warna Lentera.

Mahyarni (2013). Theory of Reasoned Action dan Theory of Planned Behavior (Sebuah Kajian Historis tentang Perilaku). Jurnal El-Riyasah, 4(1).

MurniS, GreenC, DjauziS, SetiyantoA, Okta S (2016). Hidup dengan HIV-AIDS. Jakarta: Yayasan Spiritia.
Noviana N (2016). Konsep HIV/AIDS Seksualitas dan Kesehatan Reproduksi. Jakarta Timur: CV. Trans Info Media.

Raisyifa, Mangguang M, Reflita (2010). Faktor-Faktor yang Berhubungan dengan Tindakan Pencegahan Infeksi Menular Seksual pada Pekerja Seks Komersial di Lokalisasi Teleju Pekanbaru. Jurnal Kesehatan Masyarakat, 4(1).

WHO (2013). Sexually Transmitted Infections(STIs). Switzerland: Department of Reproductive Health and Research World Health Organization.

Widodo E (2009). Praktik Wanita Pekerja Seks (WPS) dalam Pencegahan Penyakit Infeksi Menular Seksual (IMS) dan HIV/AIDS di Lokalisasi Koplak, Kabupaten Grobogan. Jurnal Promosi Kesehatan Indonesia, 4(2).

Wulandari Y, Suryani N, Poncorini E (2016). Health Belief Model: Health Preventive Behavior of Sexually Transmitted Infection in Female Sex Workers in Surakarta. Journal of Health Promotion and Behavior, 1 (2): 70-78.

Yogatama L (2013). Analisis Pengaruh Attitude, Subjective Norm, dan Perceived Behavior Control terhadap Intensi Penggunaan Helm Saat Mengendarai Motor pada Remaja dan Dewasa Muda di Jakarta Selatan. Proceeding PESAT (Psikologi, Ekonomi, Sastra, Arsitektur\& Teknik Sipil). 